\title{
ANALISIS ATP-WTP PENUMPANG KERETA REL LISTRIK LINTAS BOGOR-JAKARTA KOTA
}

\author{
Jeffry Nathanael ${ }^{1}$, Dewi Linggasari ${ }^{2}$, dan Hokbyan Angkat ${ }^{3}$ \\ ${ }^{1}$ Program Studi Sarjana Teknik Sipil, Universitas Tarumanagara, Jl. Letjen S. Parman No.1 Jakarta \\ Jeffry.325160091@stu.untar.ac.id \\ ${ }^{2}$ Program Studi Sarjana Teknik Sipil, Universitas Tarumanagara, Jl. Letjen S. Parman No.1 Jakarta \\ dewil@ft.untar.ac.id \\ ${ }^{3}$ Program Studi Sarjana Teknik Sipil, Universitas Tarumanagara, Jl. Letjen S. Parman No.1 Jakarta \\ hokbyan@gmail.com
}

Masuk: 09-01-2021, revisi: 09-02-2021, diterima untuk diterbitkan: 10-02-2021

\begin{abstract}
The determination of Kereta Rel Listrik (KRL) rates needs to consider the value of Ability to Pay (ATP) and Willingness to Pay (WTP) of service users to spend a certain amount of money for the services they get. The purpose of this research was to determine the value of the Ability to Pay (ATP) and Willingness to Pay (WTP) of KRL service users across Bogor-Jakarta Kota. The method of collecting research data online is by giving questionnaires to respondents who use KRL cross Bogor-Jakarta Kota. The research data obtained were then analyzed and information was obtained about the individual characteristics of the respondent, the characteristics of the respondent's trip, the amount of ATP value, and the amount of the WTP value. Based on the analysis results on the existing tariff of Rp. 3,000, - obtained the value of ATP and WTP is Rp. 3,770, - and Rp. 3,974, -. This shows that the tariff is smaller than ATP, smaller than WTP, so that the current rate is still affordable for users. The $100 \%$ condition for ATP and WTP sensitivity is a condition where the increased tariff is proportional to the service received.
\end{abstract}

Keywords: Ability to Pay (ATP); Willingness to Pay (WTP); KRL cross Bogor-Jakarta Kota; Tariff

\begin{abstract}
ABSTRAK
Penetapan tarif Kereta Rel Listrik (KRL) perlu mempertimbangkan antara nilai Ability to Pay (ATP) dan Willingness to Pay (WTP) pengguna jasa untuk mengeluarkan sejumlah uang demi pelayanan jasa yang didapatkannya. Tujuan dari penelitian ini adalah mengetahui besaran nilai Ability to Pay (ATP) dan Willingness to Pay (WTP) pengguna jasa KRL lintas Bogor-Jakarta Kota. Metode pengumpulan data penelitian secara online dengan cara memberikan kuesioner kepada responden yang menggunakan KRL lintas Bogor-Jakarta Kota. Data penelitian yang diperoleh kemudian dianalisis dan didapatkan informasi mengenai karakteristik individu responden, karakteristik perjalanan responden, besaran nilai ATP, dan besaran nilai WTP. Berdasarkan hasil analisis pada tarif eksisting sebesar Rp. 3.000,- didapat besaran nilai ATP dan WTP adalah Rp. 3.770,- dan Rp. 3.974,-. Hal ini menunjukkan bahwa tarif tersebut lebih kecil dari ATP lebih kecil dari WTP sehingga tarif yang diberikan saat ini masih dapat terjangkau bagi pengguna. Kondisi $100 \%$ pada sensitivitas ATP dan WTP merupakan kondisi dimana tarif yang ditingkatkan sebanding dengan pelayanan yang diterima.
\end{abstract}

Kata kunci: Ability to Pay (ATP); Willingness to Pay (WTP); KRL lintas Bogor-Jakarta Kota; Tarif

\section{PENDAHULUAN}

Kereta api merupakan moda transportasi yang diminati masyarakat hingga saat ini. Fungsi kereta api sebagai alat untuk mengangkut penumpang maupun barang. Kereta api digunakan untuk masyarakat luas sebagai penunjang roda perekonomian, termasuk masyarakat ekonomi lemah. Suatu sistem transportasi dapat dinilai berhasil dilihat dari beberapa aspek yaitu mobilitas, aksesbilitas, dan ekonomi.

Salah satu keunggulan kereta Commuter Line adalah sebagai angkutan umum yang mampu memberikan pelayanan transportasi yang efisien, cepat dan murah. Kereta Commuter line mampu mengurangi kemacetan di wilayah Jabodetabek (Jakarta, Bogor, Depok, Tangerang, Bekasi). Perlu adanya kebijakan tarif yang mempertimbangkan pengguna kendaraan pribadi untuk berpindah menggunakan KRL dengan memperhitungkan variabel-variabel yang berpengaruh dalam penggunaan moda KRL. 
Perlu adanya nilai Ability to Pay (ATP) untuk menetapkan tarif pengguna jasa kereta dalam hal membayar untuk mendapatkan pelayanan jasa yang diterima. ATP berhubungan dengan penghasilan sehingga kemampuan seseorang dalam melakukan kegiatan transportasi dapat berlangsung. Sedangkan nilai WTP mempengaruhi kualitas pelayanan yang diterima oleh pengguna jasa transportasi. Kualitas pelayanan ini sebagai bentuk usaha untuk memenuhi kebutuhan dan keinginan pelanggan untuk mengimbangi harapan pengguna

Penyedia jasa transportasi perlu mengikuti Standar Pelayanan Minimum (SPM) yang sudah ditetapkan. Sistem tiket KRL menggunakan tarif progresif berupa 25 kilometer pertama sebesar Rp. 3.000,- dan akan ditambah Rp 1.000,setiap 10 kilometer berikutnya.

Rumusan masalah yang akan dibahas adalah sebagai berikut:

- Berapa besaran nilai Ability to Pay (ATP) dan Willingness to Pay (WTP) pengguna jasa KRL lintas BogorJakarta Kota?

- Bagaimana pengaruh ATP dan WTP terhadap tarif pada pengguna jasa KRL lintas Bogor-Jakarta Kota?

Tujuan penelitian dalam sebuah penelitian berdasarkan rumusan masalah adalah sebagai berikut:

- Mengetahui besaran nilai Ability to Pay (ATP) dan Willingness to Pay (WTP) pengguna jasa KRL lintas BogorJakarta Kota

- Pengaruh ATP dan WTP terhadap tarif pengguna jasa KRL lintas Bogor-Jakarta Kota

\section{Tarif}

Tarif adalah jumlah uang yang dibutuhkan untuk mendapatkan sejumlah kombinasi dari barang beserta pelayanannya (Swastha dan Irawan). Tarif angkutan umum adalah tarif yang dikenakan pada angkutan umum. Terdapat beberapa aspek untuk menentukan besarnya seperti: kepentingan konsumen pengguna, operator pengguna jasa dan kepentingan pemerintah. Hal yang mempengaruhi tingkat tarif angkutan adalah perubahan biaya operasi alat angkutan yang ditetapkan berdasarkan biaya operasi satu unit (unit cost) dari jasa angkutan tersebut.

Peraturan Menteri Perhubungan Republik Indonesia Nomor PM 36 Tahun 2019 menjelaskan menteri dapat menetapkan tarif angkutan kepada masyarakat yang belum mampu yang ditetapkan oleh penyelenggara sarana perkeretaapian untuk angkutan pelayanan kelas ekonomi sebagai bentuk kewajiban pelayanan publik. Tarif yang diberlakukan harus lebih rendah dari tarif yang ditetapkan oleh penyelenggara sarana perkeretaapian.

\section{Ability to Pay (ATP)}

Ability To Pay (ATP) adalah kemampuan seseorang untuk membayar jasa angkutan yang diterimanya berdasarkan penghasilan yang dianggap ideal. Menurut (Tamin dan dkk) pendekatan yang digunakan dalam analisis ATP didasarkan pada alokasi biaya untuk transportasi dan pendapatan yang diterimanya. Besar ATP adalah rasio anggaran untuk untuk transportasi dengan intensitas perjalanan. Besaran ini menunjukkan kemampuan masyarakat dalam membayar ongkos perjalanan yang dilakukannya. Beberapa faktor yang mempengaruhi ATP adalah:

- Besar penghasilan penumpang

- Kebutuhan transportasi

- Total biaya transportasi

- Persentase penghasilan yang digunakan untuk biaya transportasi

\section{Willingness to Pay (WTP)}

Willingness to Pay adalah bentuk kesediaan pengguna mengeluarkan sejumlah uang atas jasa yang didapatnya (Tamin dan dkk). Pendekatan yang digunakan dalam analisis WTP didasarkan pada persepsi pengguna terhadap tarif dari jasa pelayanan angkutan umum tersebut. Beberapa faktor yang mempengaruhi WTP adalah:

- Produk yang disediakan oleh operator jasa pelayanan transportasi

- Kualitas dan kuantitas pelayanan yang diberikan

- Utilitas pengguna dalam angkutan tersebut

- Penghasilan pengguna 


\section{Hubungan ATP dan WTP}

Menurut (Safitri) terdapat 3 kondisi hubungan antara ATP dan WTP, yaitu:

- ATP lebih besar dari WTP

Kondisi ini menunjukkan kemampuan membayar jasa transportasi lebih besar daripada kemauan membayar jasa tersebut. Pada kondisi ini, besar penghasilan pengguna relatif lebih tinggi dibandingkan utilitas terhadap jasa yang relatif lebih rendah, dimana pengguna disebut choiced riders.

- ATP sama dengan WTP

Kondisi dimana kemampuan dan kemauan membayar jasa transportasi adalah sama. Hal ini dapat terjadi karena keseimbangan utilitas pengguna dengan biaya yang dikeluarkan untuk membayar jasa tersebut.

- ATP lebih kecil dari WTP

Kondisi dimana kemampuan membayar jasa transportasi lebih kecil daripada kemauan membayar. Pengguna dapat disebut captive riders karena besar penghasilan pengguna relatif lebih rendah dibandingkan utilitas terhadap jasa yang relatif lebih tinggi.

\section{Penentuan tarif berdasarkan ATP dan WTP}

Dalam menentukan tarif terdapat 3 aspek utama pada sistem angkutan umum, yaitu pengguna (user), operator, dan pemerintah (regulator) (Safitri). Aspek pengguna merupakan aspek yang utama untuk menentukan tarif ATP dan WTP.

Prinsip-prinsip dalam menentukan nilai tarif berdasarkan ATP dan WTP adalah sebagai berikut

- ATP merupakan fungsi dari kemampuan daya beli untuk membayar yang dimana nilai tarif yang diberlakukan tidak melebihi nilai ATP kelompok sasaran. Intervensi/campur tangan pemerintah dalam bentuk subsidi langsung atau silang dibutuhkan bila nilai tarif lebih besar dari nilai ATP, sehingga nilai tarif tersebut sama besarnya dengan nilai ATP.

- WTP merupakan fungsi dari tingkat pelayanan angkutan umum, peningkatan nilai tarif dengan adanya perbaikan tingkat pelayanan angkutan umum dapat dilakukan bila nilai WTP masih dibawah ATP.

- WTP merupakan fungsi dari tingkat pelayanan angkutan umum, sehingga bila nilai WTP masih dibawah ATP

\section{METODE PENELITIAN}

\section{Jenis penelitian}

Jenis penelitian yang dilakukan adalah penelitian deskriptif kuantitatif untuk menggambarkan karakteristik responden, besaran nilai ATP, dan besaran nilai WTP pengguna jasa transportasi KRL.

\section{Metode pengumpulan data}

Pengumpulan data didapat dari data primer. Respon yang diberikan langsung dari penumpang Kereta Bandara secara online menggunakan kuesioner. Karena kondisi dimana terdapat banyak keterbatasan yakni tidak dapat mengklarifikasi responden dalam situasi pandemi covid-19 sehingga hanya menyebarkan kusioner secara online.

\section{Metode analisis data}

Analisis masalah berdasarkan hasil-hasil yang didapat dari pengolahan data terdiri dari analisis karakteristik responden, analisis ATP, dan analisis WTP.

- Analisis Karakteristik Responden

Data karakteristik responden yang diperoleh dari kuesioner kemudian dimasukkan ke dalam tabel rekapitulasi. Hasil data yang diperoleh dapat dianalisis dan ditampilkan dalam bentuk tabel dan grafik.

- Analisis ATP

Data ATP responden yang diperoleh dari kuesioner kemudian dimasukkan ke dalam tabel rekapitulasi. Hasil data yang diperoleh dapat dianalisis dan ditampilkan dalam bentuk diagram ATP responden. Berikut merupakan rumus untuk menghitung nilai besaran ATP responden

$$
A T P_{\text {rata-rata }}=\frac{i}{n} \sum_{i=1}^{n} A T P_{i}
$$


- Analisis WTP

Data Data WTP responden yang diperoleh dari kuesioner kemudian dimasukan ke dalam tabel rekapitulasi. Hasil data yang diperoleh dapat dianalisis dan ditampilkan dalam bentuk diagram WTP responden.

Nilai besaran WTP responden dihitung dengan menggunakan rumus:

$$
W T P_{\text {rata-rata }}=\frac{i}{n} \sum_{i=1}^{n} W T P_{i}
$$

\section{HASIL DAN PEMBAHASAN}

\section{Data responden}

Survei ini dilakukan secara online dengan cara penyebaran kuesioner melalui Google Forms. Hasil dari kuesioner yang telah diisi oleh responden akan dikumpulkan sehingga memperoleh data penelitian ini. Formulir kuesioner yang diajukan kepada responden.

\section{Karaksteristik individu responden}

- Jenis Kelamin

Data jenis kelamin responden didominasi laki-laki sebesar 73\% selengkapnya dapat dilihat pada Gambar 1.

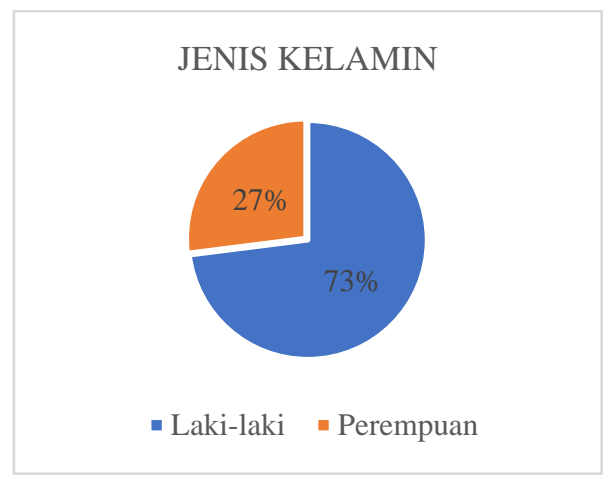

Gambar 1. Jenis kelamin responden KRL lintas Bogor-Jakarta Kota

- Usia

Data usia responden didominasi berusia 21-30 tahun sebesar 75\% selengkapnya dapat dilihat pada Gambar 2.

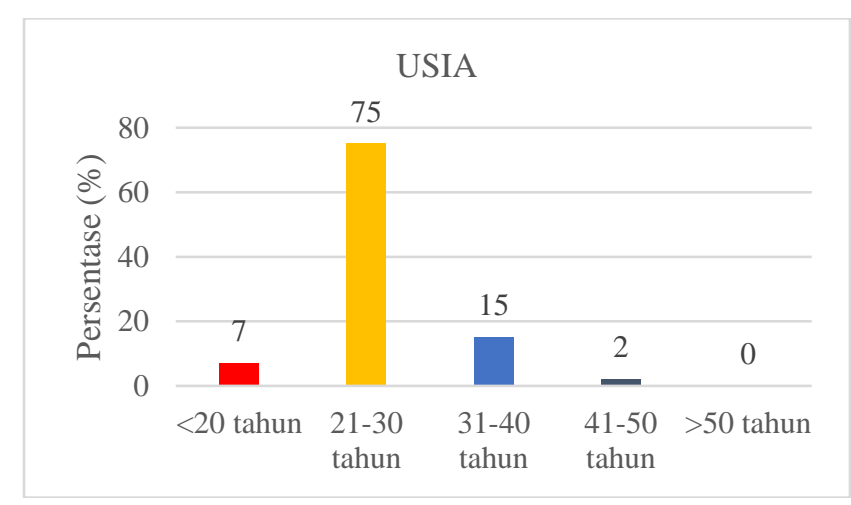

Gambar 2. Usia responden KRL lintas Bogor-Jakarta Kota

- Wilayah Tempat Tinggal

Data tempat tinggal responden pada penelitian ini terbanyak domisili Kab. Bogor sebesar $41 \%$ selengkapnya dapat dilihat pada Gambar 3. 


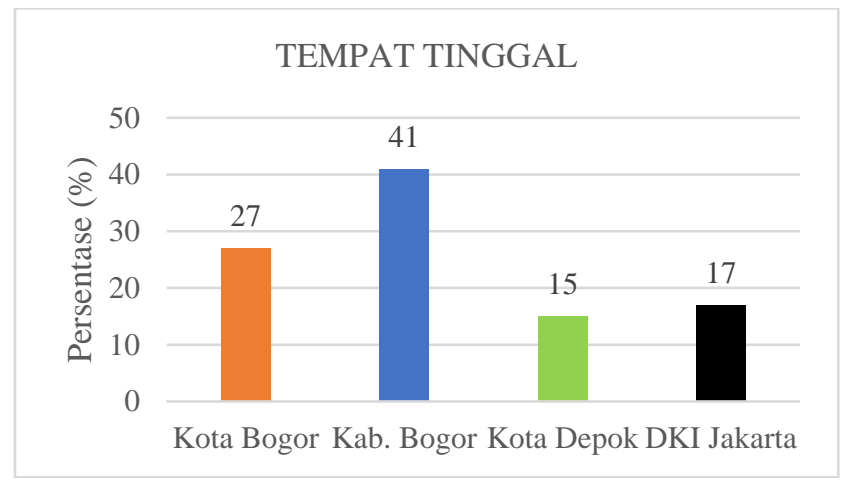

Gambar 3. Tempat tinggal responden KRL lintas Bogor-Jakarta Kota

- Pendidikan

Data pendidikan responden pada penelitian ini sebesar $62 \%$ lulusan S1 selengkapnya dapat dilihat pada Gambar 4.

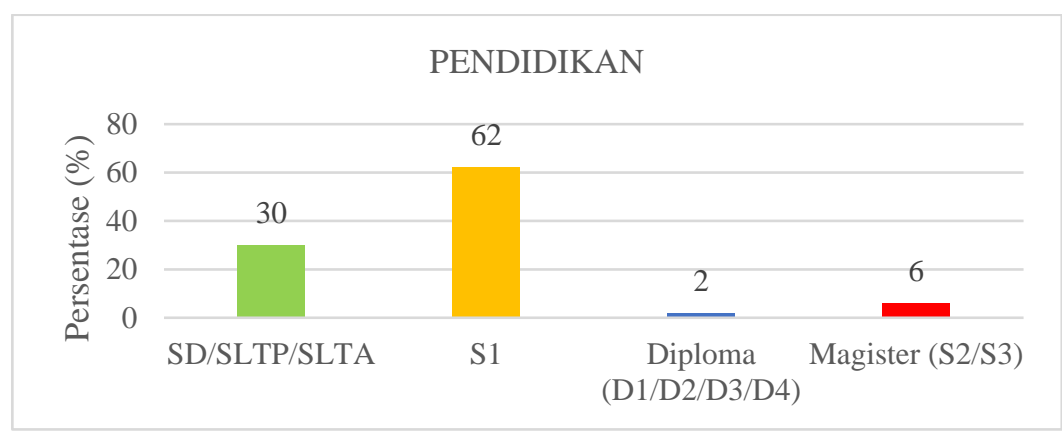

Gambar 4. Pendidikan responden KRL lintas Bogor-Jakarta Kota

- Pekerjaan

Data pekerjaan responden didominasi oleh pelajar/mahasiswa sebesar $46 \%$ selengkapnya dapat dilihat pada Gambar 5.

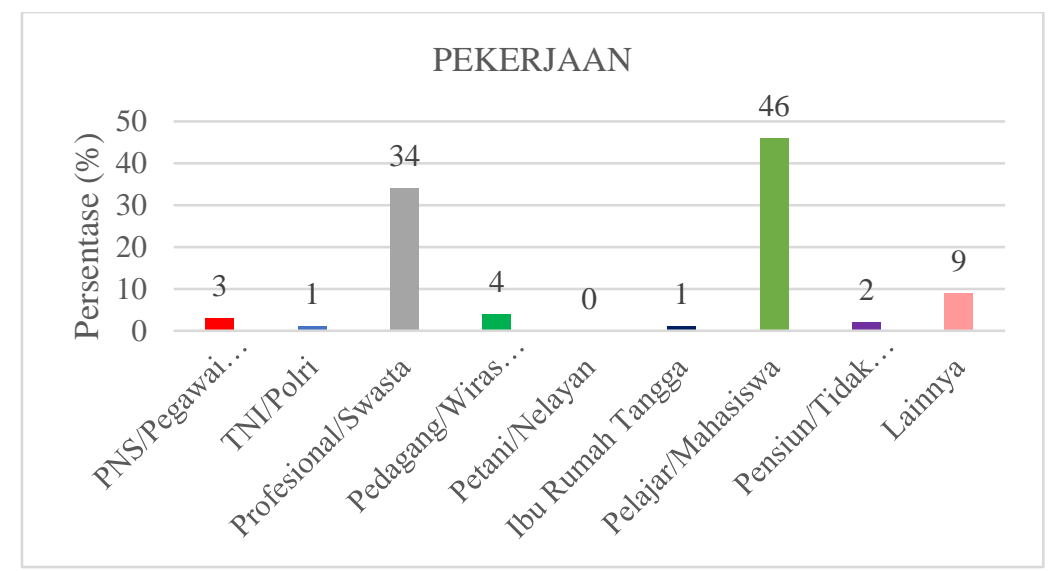

Gambar 5. Pekerjaan responden KRL lintas Bogor-Jakarta Kota

- Pendapatan bulanan

Data penghasilan bulanan responden pada penelitian ini sebesar $50 \%$ berpenghasilan $\leq$ Rp. 2.500 .000 selengkapnya dapat dilihat pada Gambar 6. 


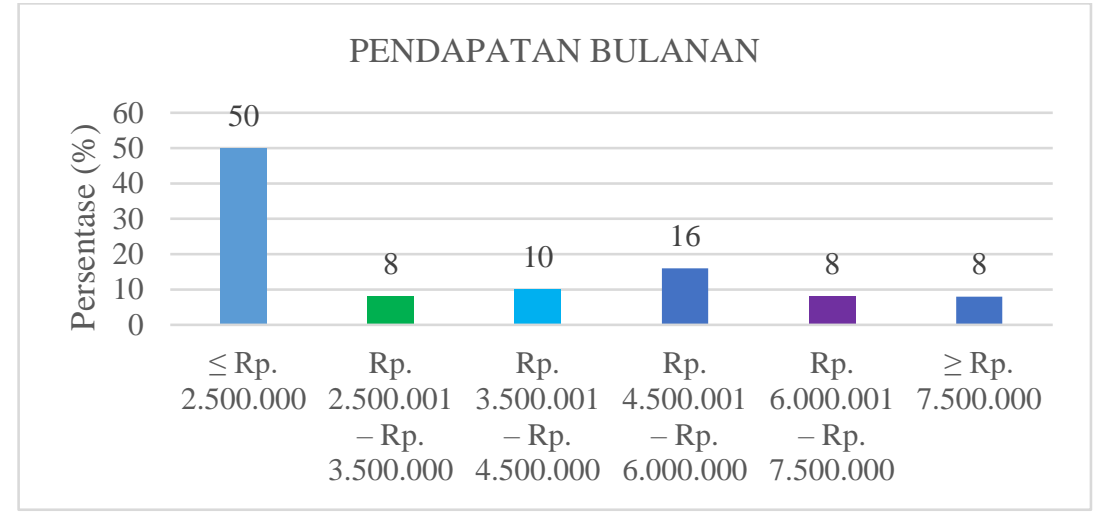

Gambar 6. Pendapatan bulanan responden KRL lintas Bogor-Jakarta Kota

- Jumlah keluarga yang ditanggung

Data jumlah keluarga yang ditanggung pada penelitian ini mayoritas adalah tidak ada sebsear $85 \%$ selengkapnya dapat dilihat pada Gambar 7.

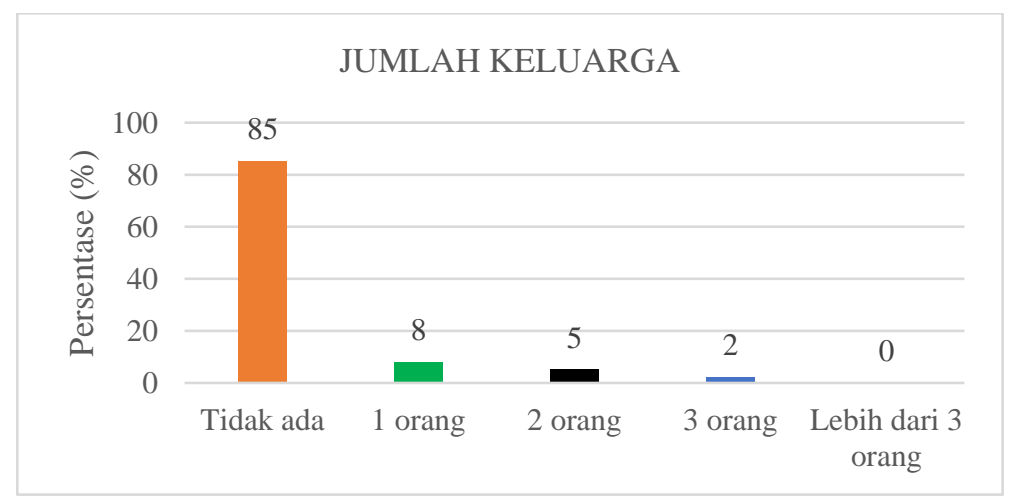

Gambar 7. Jumlah keluarga yang ditanggung responden KRL lintas Bogor-Jakarta Kota

\section{Karakteristik perjalanan responden}

- Penggunaan KRL

Data penggunaan KRL responden pada penelitian ini sebanyak lebih dari 3 kali sebesar $94 \%$ selengkapnya dapat dilihat pada Gambar 8.

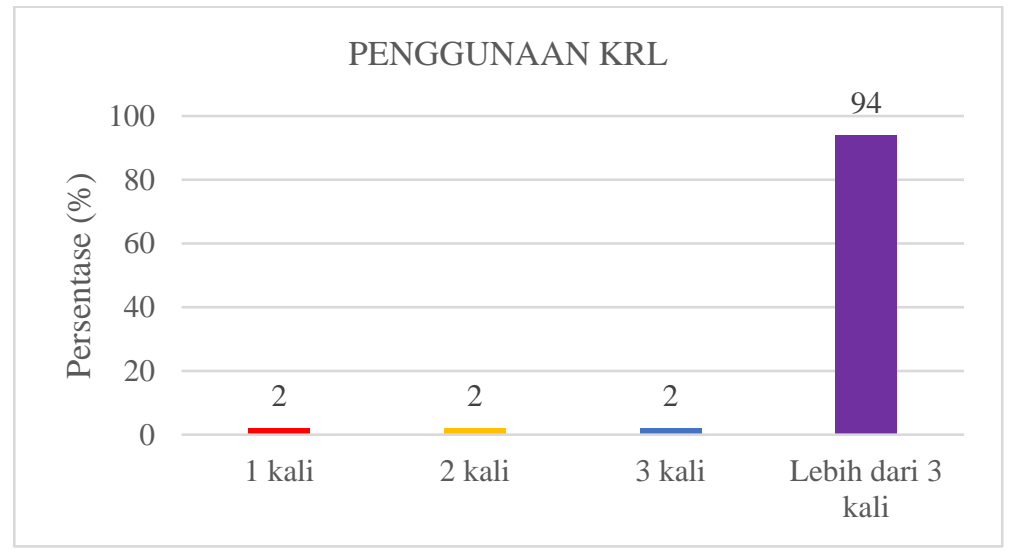

Gambar 8. Penggunaan KRL responden KRL lintas Bogor-Jakarta Kota 
- Frekuensi penggunaan KRL

Data frekuensi penggunaan KRL responden pada penelitian ini sebesar $73 \%$ menjawab sesuai kebutuhan selengkapnya dapat dilihat pada Gambar 9.

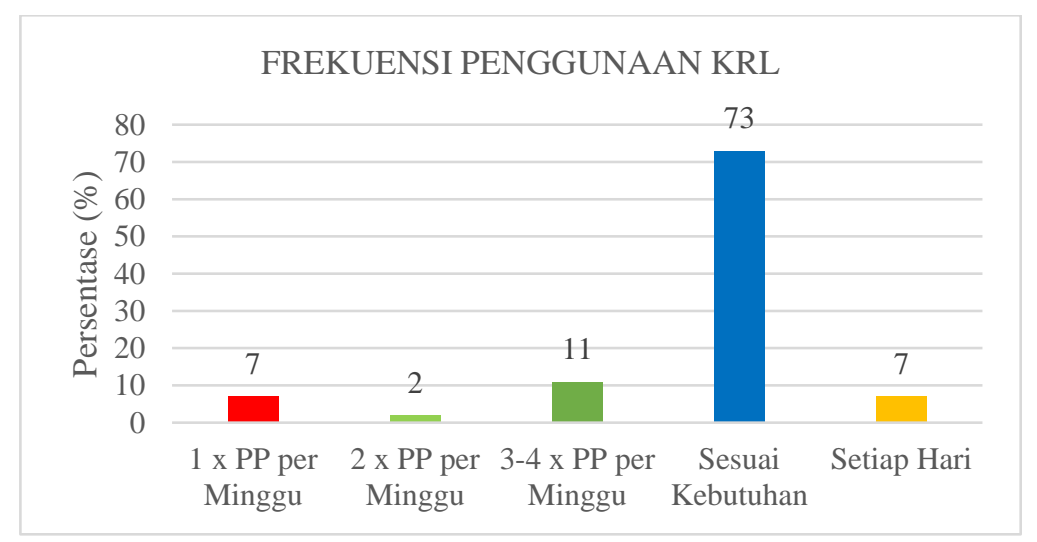

Gambar 9. Frekuensi perjalanan responden KRL lintas Bogor-Jakarta Kota

- Maksud Perjalanan

Data maksud perjalanan responden pada penelitian ini sebesar 37\% untuk sekolah/pulang dapat dilihat pada Gambar 10

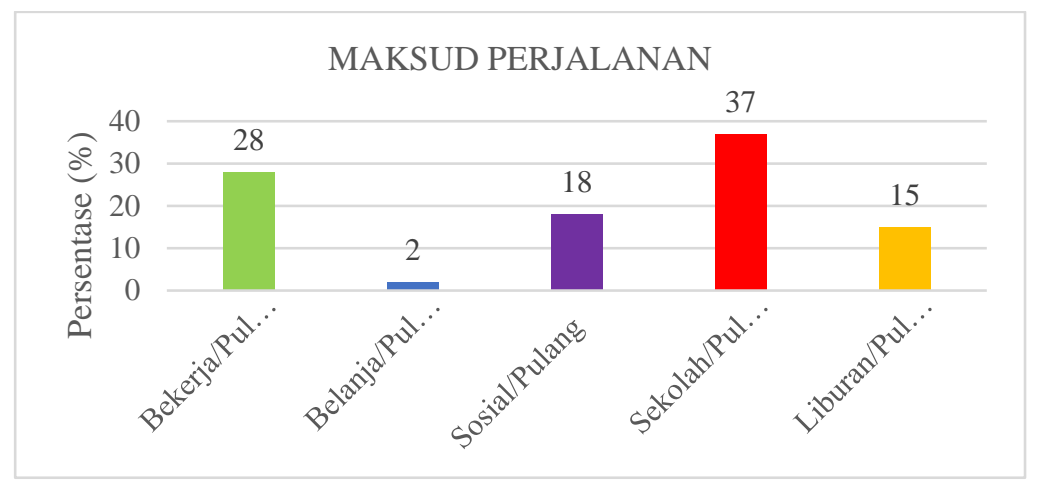

Gambar 10. Maksud perjalanan responden KRL lintas Bogor-Jakarta Kota

- Stasiun keberangkatan

Data stasiun keberangkatan responden pada penelitian ini mayoritas dari Stasiun Bogor sebesar 31\% selengkapnya dapat dilihat pada Gambar 11.

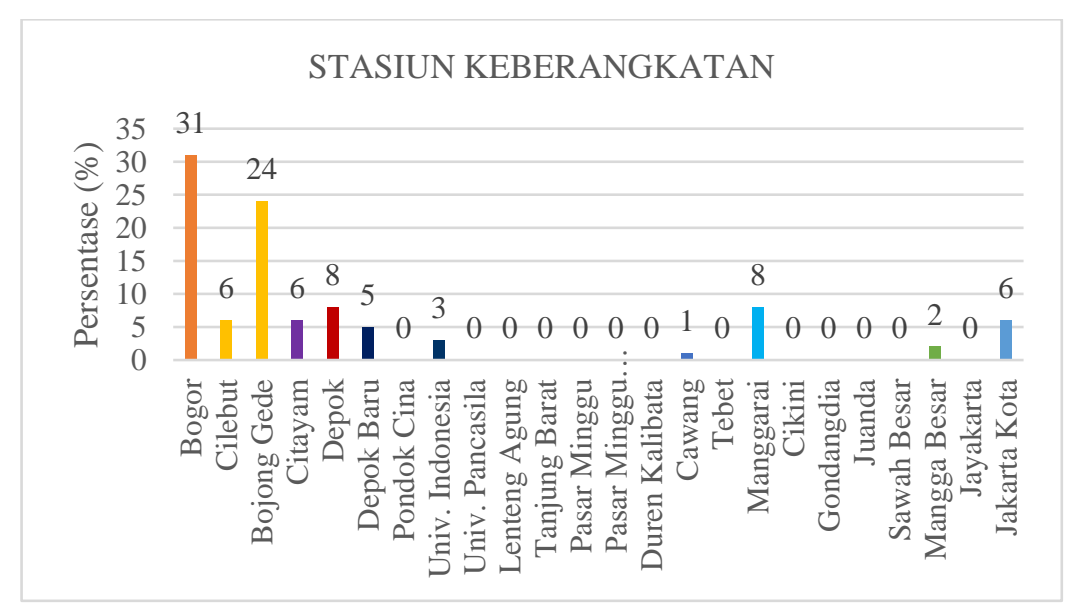

Gambar 11. Stasiun keberangkatan responden KRL lintas Bogor-Jakarta Kota 
- Stasiun tujuan

Data stasiun tujuan responden pada penelitian ini terbanyak menuju Stasiun Univ. Indonesia sebsar 17\% selengkapnya dapat dilihat pada Gambar 12.

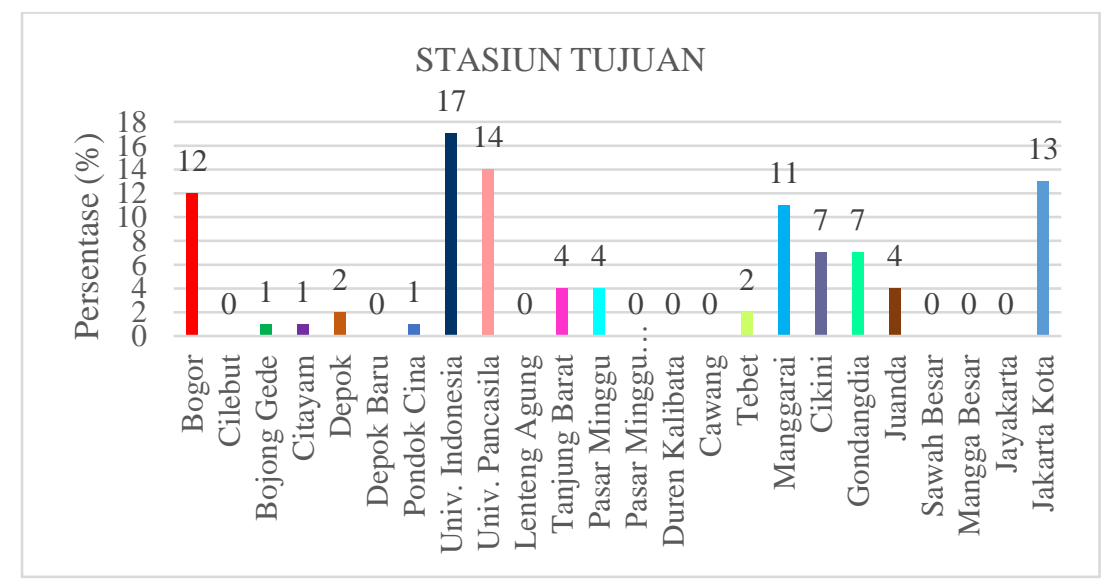

Gambar 12. Stasiun tujuan responden KRL lintas Bogor-Jakarta Kota

- Moda menuju/dari stasiun

Data maksud perjalanan responden pada penelitian ini sebesar $29 \%$ menggunakan angkutan umum selengkapnya dapat dilihat pada Gambar 13.

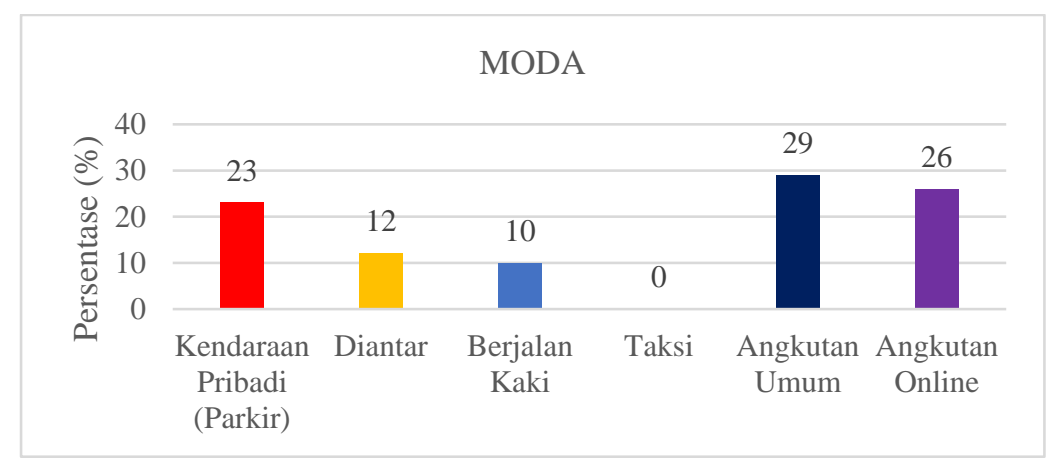

Gambar 13. Moda responden pada saat datang/berangkat ke /dari stasiun KRL lintas Bogor-Jakarta Kota

- Tarif KRL

Data tarif KRL responden pada penelitian ini terbanyak pada tarif Rp. 3.000 sebesar 35\% dapat dilihat pada Gambar 14.

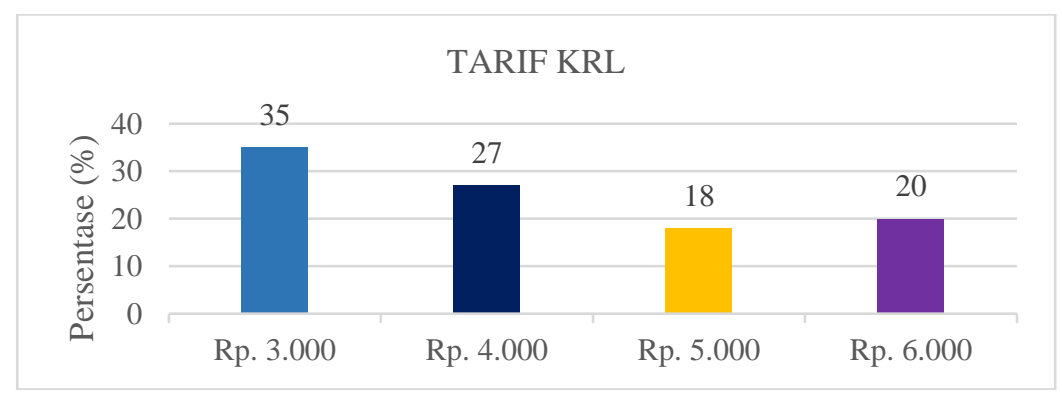

Gambar 14. Tarif responden KRL lintas Bogor-Jakarta Kota

- Biaya angkutan ke/dari stasiun dari/ke rumah

Data biaya angkutan responden pada penelitian ini sekitar Rp. 5.001 - Rp. 10.000 sebesar 37\% selengkapnya dapat dilihat pada Gambar 15. 


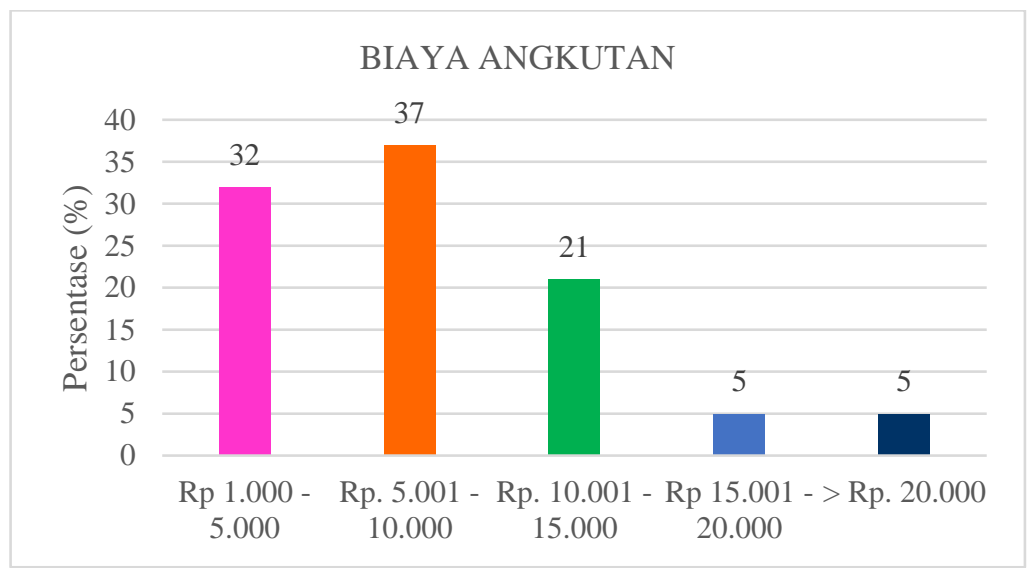

Gambar 15. Biaya angkutan responden KRL lintas Bogor-Jakarta Kota

- Persentase total alokasi untuk biaya transportasi per bulan

Data persentase total alokasi untuk biaya transportasi per bulan responden pada penelitian ini sebesar 53\% menjawab $>10 \%$ selengkapnya dapat dilihat pada Gambar 16 .

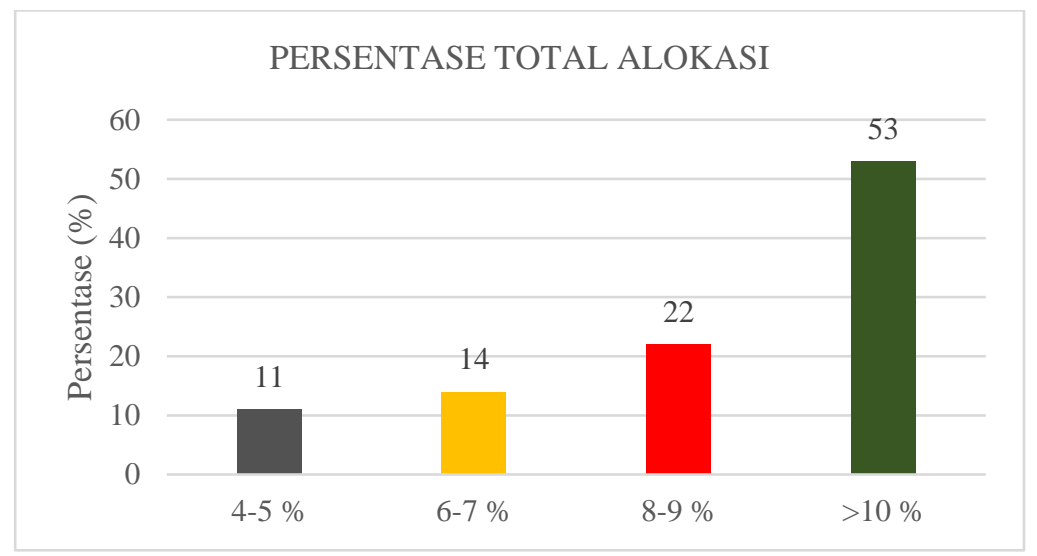

Gambar 16. Persentase total alokasi untuk biaya transportasi per bulan responden KRL lintas Bogor-Jakarta Kota

\section{Analisis ATP}

- Alasan penggunaan KRL

Data alasan penggunaan KRL responden pada penelitian ini $71 \%$ lebih murah dan $61 \%$ lebih cepat/tepat waktu selengkapnya dapat dilihat pada Gambar 17.

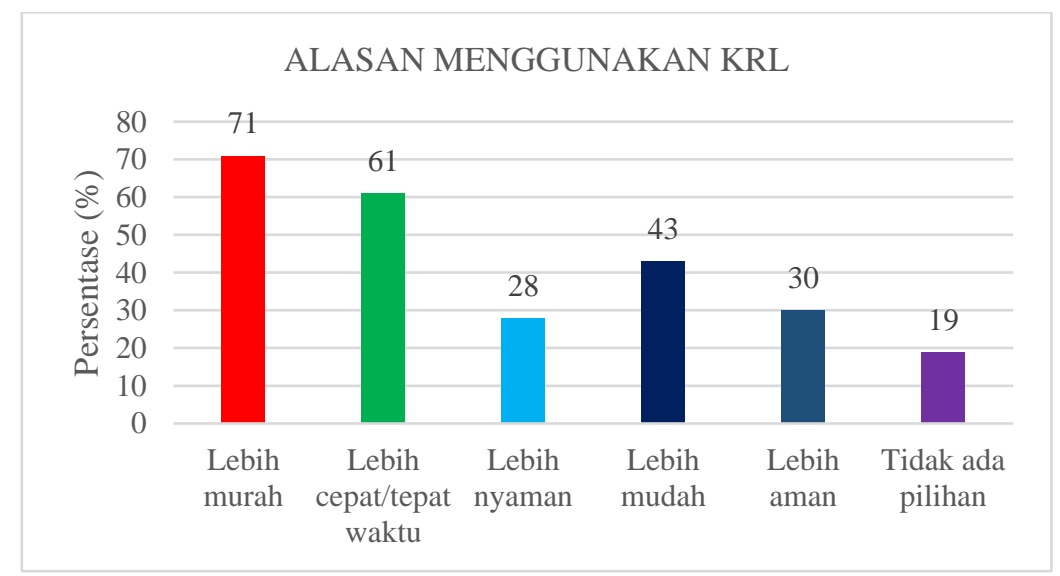

Gambar 17. Alasan responden menggunakan KRL lintas Bogor-Jakarta Kota 
- Besaran nilai ATP

Data frekuensi ATP responden KRL litnas Bogor-Jakarta Kota dapat dilihat pada Tabel 1 .

Tabel 1. Frekuensi ATP responden KRL lintas Bogor-Jakarta Kota

\begin{tabular}{cccccc}
\hline \multirow{2}{*}{ ATP } & \multicolumn{5}{c}{ Tarif (Rp) } \\
\cline { 2 - 5 } & 3000 & 4000 & 5000 & 6000 & Total \\
\hline Tarif Eksisting & 35 & 27 & 18 & 20 & 100 \\
Tarif Naik 10\% & 35 & 27 & 18 & 20 & 100 \\
Tarif Naik 20\% & 33 & 20 & 14 & 14 & 81 \\
Tarif Naik 30\% & 25 & 16 & 11 & 13 & 65 \\
Tarif Naik 40\% & 20 & 10 & 8 & 8 & 46 \\
Tarif Naik 50\% & 14 & 5 & 7 & 6 & 32 \\
\hline
\end{tabular}

Data persentase ATP responden KRL lintas Bogor-Jakarta Kota dapat dilihat pada Tabel 2.

Tabel 2. Persentase ATP responden KRL lintas Bogor-Jakarta Kota

\begin{tabular}{ccccc}
\hline \multirow{2}{*}{ ATP } & \multicolumn{4}{c}{ Tarif (Rp) } \\
\cline { 2 - 5 } & 3000 & 4000 & 5000 & 6000 \\
\hline Tarif Naik 10\% & $100 \%$ & $100 \%$ & $100 \%$ & $100 \%$ \\
Tarif Naik 20\% & $94 \%$ & $74 \%$ & $78 \%$ & $70 \%$ \\
Tarif Naik 30\% & $71 \%$ & $59 \%$ & $61 \%$ & $65 \%$ \\
Tarif Naik 40\% & $57 \%$ & $37 \%$ & $44 \%$ & $40 \%$ \\
Tarif Naik 50\% & $40 \%$ & $18 \%$ & $33 \%$ & $30 \%$ \\
\hline
\end{tabular}

Berikut adalah contoh perhitungan besaran nilai ATP rata-rata KRL lintas Bogor-Jakarta Kota untuk tarif Rp. 3.000,- berdasarkan Persamaan 1. Data selengkapnya dapat dilihat pada Tabel 3.

$$
\begin{aligned}
\text { ATP Rata-rata } & =\frac{3300 \times 35+3600 \times 33+3900 \times 25+4200 \times 20+4500 \times 14}{35+33+25+20+14} \\
& =\quad \text { Rp. } 3.770,-
\end{aligned}
$$

Tabel 3. ATP rata-rata KRL lintas Bogor-Jakarta Kota

\begin{tabular}{ccc}
\hline Tarif (Rp) & ATP Rata-rata (Rp) & Selisih Tarif dan ATP Rata-rata (Rp) \\
\hline 3000 & 3770 & 770 \\
4000 & 4923 & 923 \\
5000 & 6258 & 1258 \\
6000 & 7465 & 1465 \\
\hline
\end{tabular}


- Sensitivitas besaran nilai ATP Sensitivitas besaran nilai ATP responden KRL Lintas Bogor-Jakarta Kota dapat dilihat pada Gambar 18 dan Gambar 19.

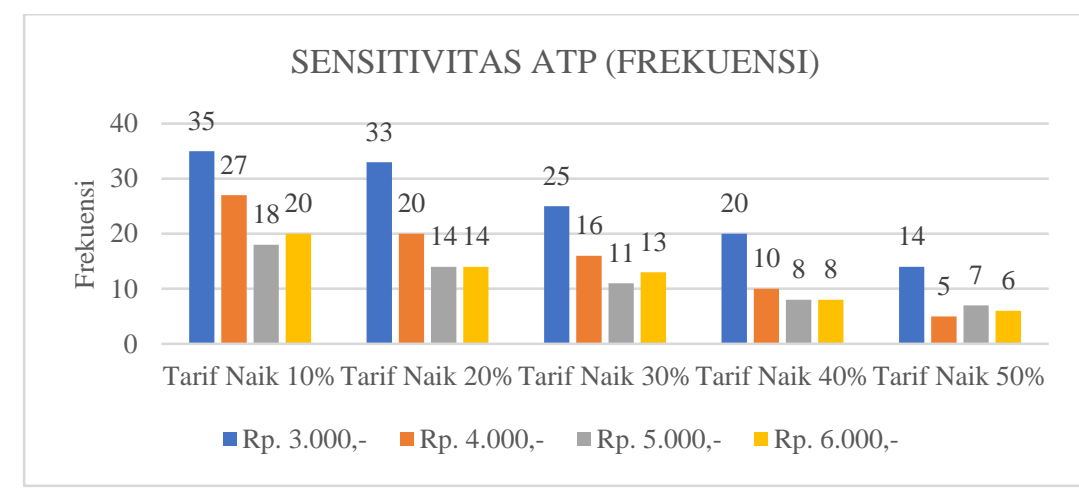

Gambar 18. Sensitivitas ATP (frekuensi) KRL lintas Bogor-Jakarta Kota

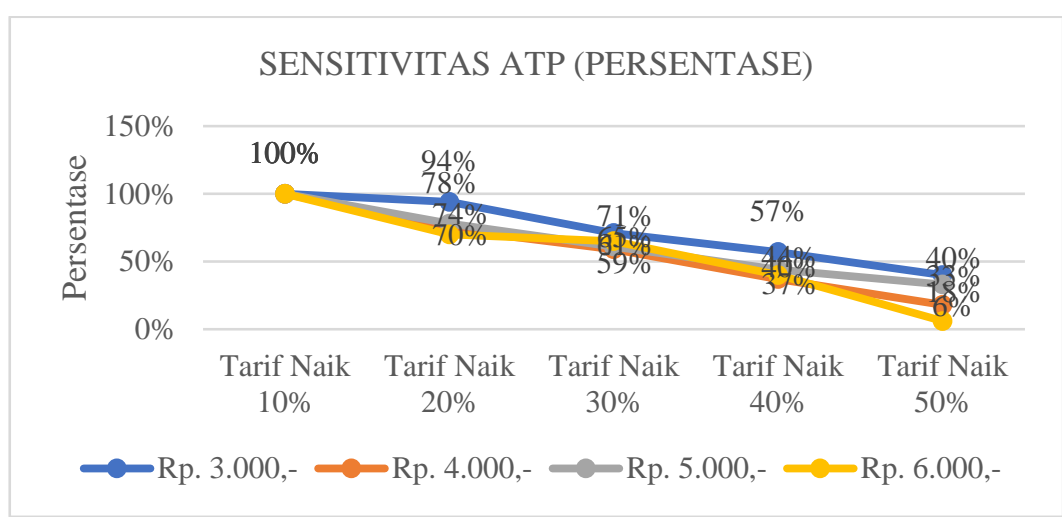

Gambar 19. Sensitivitas ATP (persentase) KRL lintas Bogor-Jakarta Kota

\section{Analisis WTP}

- Peningkatan pelayanan KRL

Data harapan peningkatan pelayanan KRL responden pada penelitian ini $71 \%$ ketersediaan kereta dan $67 \%$ kenyamanan selengkapnya dapat dilihat pada Gambar 20.

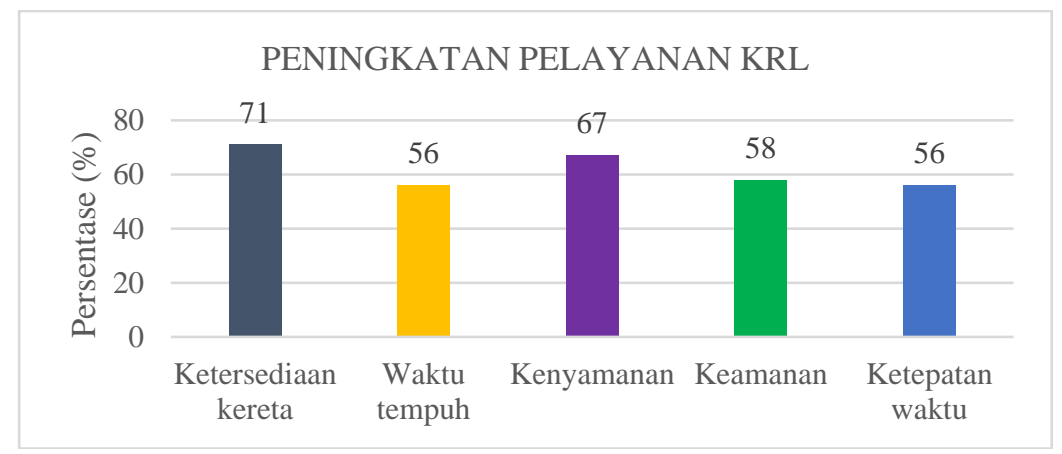

Gambar 20. Peningkatan pelayanan KRL lintas Bogor-Jakarta Kota

- Besaran nilai WTP

Data frekuensi WTP responden KRL lintas Bogor-Jakarta Kota dapat dilihat pada Tabel 4. 
Tabel 4. Frekuensi WTP responden KRL lintas Bogor-Jakarta Kota

\begin{tabular}{ccccc}
\hline WTP & \multicolumn{5}{c}{ Tarif (Rp) } \\
\cline { 2 - 5 } & 3000 & 4000 & 5000 & 6000 \\
\hline Tarif Eksisting & 35 & 27 & 18 & 20 \\
Tarif Naik Rp. 500,- & 35 & 27 & 18 & 20 \\
Tarif Naik Rp. 1.000,- & 34 & 26 & 18 & 20 \\
Tarif Naik Rp. 1.500,- & 30 & 26 & 16 & 19 \\
Tarif Naik Rp. 2.000,- & - & 25 & 14 & 15 \\
Tarif Naik Rp. 2.500,- & - & - & 10 & 13 \\
Tarif Naik Rp. 3.000,- & - & - & - & 9 \\
\hline
\end{tabular}

Data persentase WTP responden KRL lintas Bogor-Jakarta Kota dapat dilihat pada Tabel 5.

Tabel 5. Persentase WTP responden KRL lintas Bogor-Jakarta Kota

\begin{tabular}{ccccc}
\hline & \multicolumn{4}{c}{ Tarif (Rp) } \\
\cline { 2 - 5 } WTP & 3000 & 4000 & 5000 & 6000 \\
\hline Tarif Naik Rp. 500,- & $100 \%$ & $100 \%$ & $100 \%$ & $100 \%$ \\
Tarif Naik Rp. 1.000,- & $97 \%$ & $96 \%$ & $100 \%$ & $100 \%$ \\
Tarif Naik Rp. 1.500,- & $86 \%$ & $96 \%$ & $89 \%$ & $95 \%$ \\
Tarif Naik Rp. 2.000,- & - & $93 \%$ & $78 \%$ & $75 \%$ \\
Tarif Naik Rp. 2.500,- & - & - & $56 \%$ & $65 \%$ \\
Tarif Naik Rp. 3.000,- & - & - & - & $45 \%$ \\
\hline
\end{tabular}

Berikut adalah contoh perhitungan besaran nilai WTP rata-rata KRL lintas Bogor-Jakarta Kota untuk tarif Rp. 6.000,- berdasarkan Persamaan 2. Data selengkapnya dapat dilihat pada Tabel 6.

WTP Rata-rata KRL lintas Bogor-Jakarta Kota $=\frac{6500 \times 20+7000 \times 20+7500 \times 19+8000 \times 15+8500 \times 13+9000 \times 9}{20+20+19+15+13+9}$

$$
=\quad \text { Rp. 7.541,- }
$$

Tabel 6. WTP rata-rata KRL lintas Bogor-Jakarta Kota

\begin{tabular}{ccc}
\hline Tarif $(\mathrm{Rp})$ & WTP Rata-rata $(\mathrm{Rp})$ & Selisih Tarif dan WTP Rata-rata (Rp) \\
\hline 3000 & 3974 & 974 \\
4000 & 5235 & 1235 \\
5000 & 6368 & 1368 \\
6000 & 7541 & 1541 \\
\hline
\end{tabular}


- Senstivitas besaran nilai WTP

Sensitivitas besaran nilai WTP responden KRL lintas Bogor-Jakarta Kota dapat dilihat pada Gambar 21 dan Gambar 22.

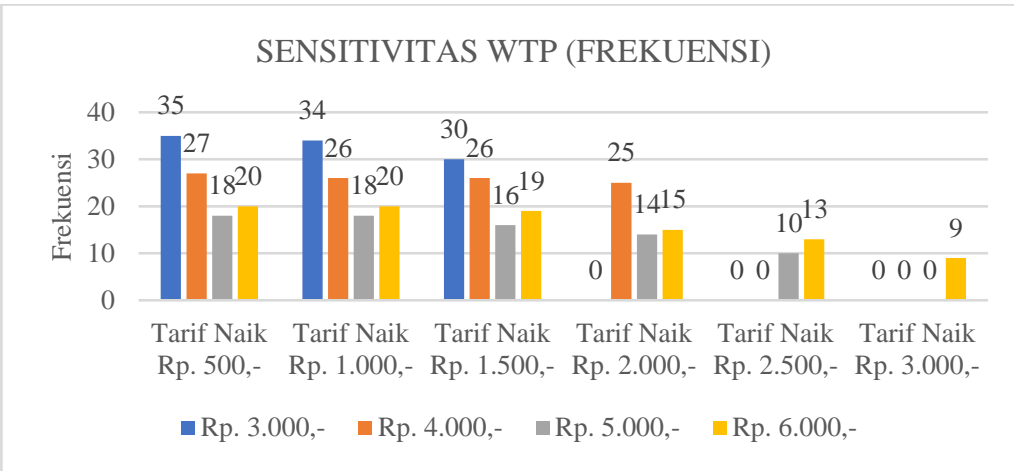

Gambar 21. Sensitivitas WTP (frekuensi) KRL lintas Bogor-Jakarta Kota

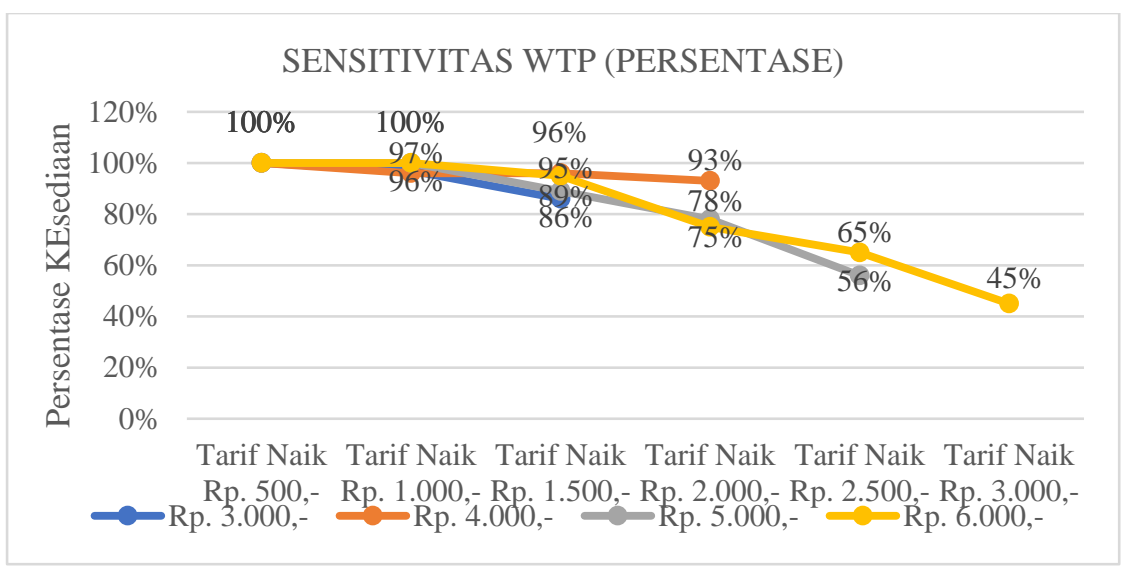

Gambar 22. Sensitivitas WTP (persentase) KRL lintas Bogor-Jakarta Kota

\section{Analisis ATP dan WTP terhadap tarif KRL lintas Bogor-Jakarta Kota}

Besaran nilai ATP rata-rata dan WTP rata-rata responden terhadap tarif KRL dapat dilihat pada Tabel 7.

Tabel 7. ATP dan WTP terhadap tarif KRL lintas Bogor-Jakarta Kota

\begin{tabular}{ccc}
\hline Tarif $(\mathrm{Rp})$ & ATP Rata-rata $(\mathrm{Rp})$ & WTP Rata-rata $(\mathrm{Rp})$ \\
\hline 3000 & 3770 & 3974 \\
4000 & 4923 & 5235 \\
5000 & 6258 & 6368 \\
6000 & 7465 & 7541 \\
\hline
\end{tabular}

Sensitivitas besaran nilai ATP rata-rata dan WTP rata-rata responden terhadap tarif KRL dapat dilihat pada Gambar 23. 


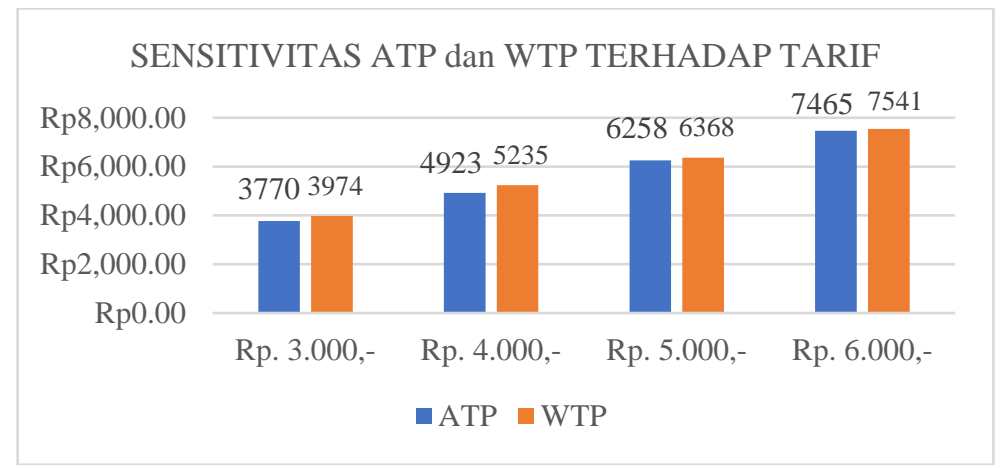

Gambar 23. Sensitivitas ATP dan WTP terhadap tarif KRL lintas Bogor-Jakarta Kota

Pembahasan dari analisis ATP dan WTP terhadap tarif KRL lintas Bogor-Jakarta Kota pada Gambar 24 dan Gambar 25.

- Pengguna KRL lintas Bogor-Jakarta Kota untuk tingkat tarif Rp. 3.000,- diperoleh nilai ATP rata-rata = Rp. 3.770,- dan nilai WTP rata-rata $=$ Rp. 3.974,-. Dari hasil data tersebut menunjukkan bahwa besaran nilai WTP > ATP > tarif, sehingga mempunyai keleluasaan untuk meningkatkan tarif hingga ATP rata-rata sebesar Rp. 770,- tanpa adanya perbaikan tingkat pelayanan.

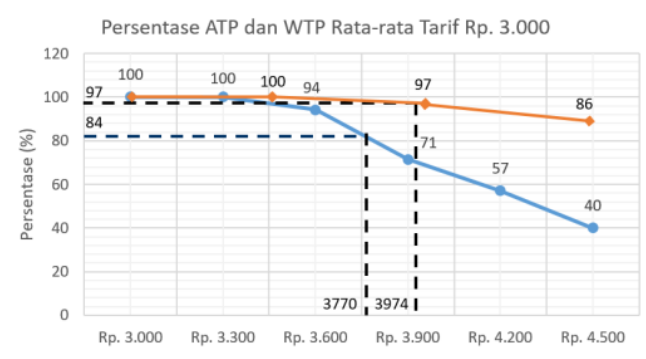

Gambar 24. Persentase ATP dan WTP rata-rata tarif Rp. 3.000,-

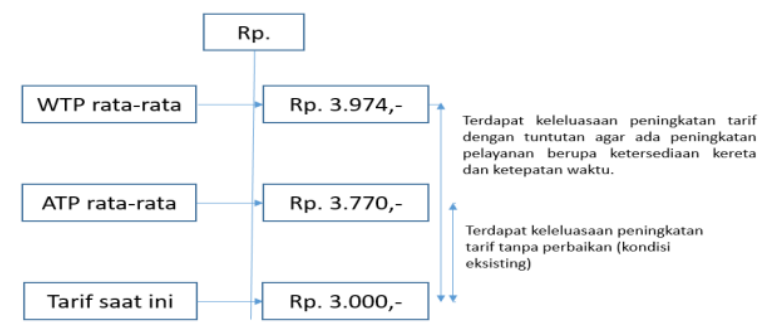

Gambar 25. Pengguna KRL lintas Bogor-Jakarta Kota pada tarif Rp. 3.000,-

\section{KESIMPULAN DAN SARAN}

\section{Kesimpulan}

Berdasarkan hasil dan pembahasan penelitian ini dapat disimpulkan sebagai berikut:

- Faktor utama yang mempengaruhi pengguna KRL dari segi ATP didasari oleh tarif yang lebih murah sedangkan dari segi WTP diharapkan adanya peningkatan ketersediaan kereta.

- Potensi kenaikan tarif KRL dari segi ATP adalah sebagai berikut:

a. Tarif Rp. 3.000,- memiliki potensi kenaikan sebesar Rp. 770.- (71\% lebih murah dan $61 \%$ lebih cepat/tepat waktu)

b. Tarif Rp. 4.000,- memiliki potensi kenaikan sebesar Rp. 923.- (71\% lebih murah dan $61 \%$ lebih cepat/tepat waktu) 
c. Tarif Rp. 5.000,- memiliki potensi kenaikan sebesar Rp. 1.258.- (71\% lebih murah dan 61\% lebih cepat/tepat waktu)

d. Tarif Rp. 6.000,- memiliki potensi kenaikan sebesar Rp. 1.465.- (71\% lebih murah dan $61 \%$ lebih cepat/tepat waktu)

- Potensi kenaikan tarif KRL dari segi WTP adalah sebagai berikut:

a. Tarif Rp. 3.000,- memiliki potensi kenaikan sebesar Rp. 974.- (71\% ketersediaan kereta dan 56\% ketepatan waktu)

b. Tarif Rp. 4.000,- memiliki potensi kenaikan sebesar Rp. 1.235.- (71\% ketersediaan kereta dan $67 \%$ kenyamanan)

c. Tarif Rp. 5.000,- memiliki potensi kenaikan sebesar Rp. 1.368.- (71\% ketersediaan kereta dan $67 \%$ kenyamanan)

d. Tarif Rp. 6.000,- memiliki potensi kenaikan sebesar Rp. 1.541.- (71\% ketersediaan kereta dan $67 \%$ kenyamanan)

- Kondisi $100 \%$ pada sensitivitas ATP dan WTP merupakan kondisi dimana tarif yang ditingkatkan sebanding dengan pelayanan yang diterima.

\section{Saran}

Berdasarkan hasil dan pembahasan penelitian ini dapat diberikan saran sebagai berikut:

- Dari segi ATP, operator mempunyai keleluasaan untuk meningkatkan tarif tanpa perlu adanya perbaikan pelayanan dikarenakan tarif yang berlaku saat ini lebih rendah dari besaran nilai ATP rata-rata. Peningkatan tarif tersebut harus mempertimbangkan tingkat penerimaan penumpang yang pada dasarnya mayoritas memilih KRL.

- Dari segi WTP, pengguna dapat menerima kenaikan tarif hingga WTP rata-rata dengan tuntutan agar ada peningkatan pelayanan tetapi pada saat penetapan tarif, pemerintah harus mempertimbangkan besaran nilai ATP.

- Penelitian ini dilakukan saaat pandemi covid-19 yang terjadi di Indonesia sehingga penulis hanya melakukan survei secara online untuk mendapatkan hasil data kusioner, Hal ini berakibat hasil yang diperoleh tidak maksimal maka disarankan untuk melakukan survei offline secara tatap muka untuk dapat dikonfirmasi langsung oleh responden.

\section{DAFTAR PUSTAKA}

Basuki, Imam dan Steven Chuadinata. “Analisis Ability To Pay dan Willingness to Pay Jasa Kereta Api.” Spektran (2019): 140-146.

Safitri, Revy. "Evaluasi Tarif Angkutan Umum berdasarkan Ability to Pay (ATP) dan Willingness to Pay (WTP) di kota Pangkalpinang." Fropil (2016).

Swastha, Basu dan Irawan. Manajemen Pemasaran Modern. Yogyakarta, 2005.

Tamin, Ofyar Z dan dkk. "Evaluasi Tarif Angkutan Umum dan Analisis Abilitiy To Pay (ATP) dan Willingness To Pay (WTP) di DKI Jakarta.” Transportasi Forum Studi Transportasi Antar Perguruan Tinggi (FSTPT) (1999).

Wulansari, Dwi N dan Milla D Astari. “Analisis Ability to Pay (ATP) dan Willingness to Pay (WTP) Pengguna Jakarta Light Rail Transit (Jakarta LRT).”(2017): 14. 